\title{
How 'RELIGIOUS' IS RELIGION AND HOW 'NATURAL' IS NATURALNESS? ON THE QUESTION OF THE NATURALNESS OF RELIGION
}

Author:

Daniël P. Veldsman

\section{Affiliation:}

${ }^{1}$ Department of Dogmatics and Christian Ethics,

University of Pretoria,

South Africa

Correspondence to:

Daniël Veldsman

email:

danie.veldsman@up.ac.za

Postal address:

Department of Dogmatics and Christian Ethics,

University of Pretoria,

Pretoria 0002, South Africa

Keywords:

evolutionary epistomology; nature; naturalism;

naturalness of religion;

religion; supernatural

Dates:

Received: 04 June 2010

Accepted: 28 Sept. 2010

Published: 22 Nov. 2010

How to cite this article:

Veldsman, D.P., 2010,

'How 'religious' is religion

and how 'natural' is

naturalness? On the

question of the naturalness

of religion', Verbum et

Ecclesia 31(1), Art. \#403,

5 pages. DOI: $10.4102 /$

ve.v31i1.403

\section{This article is available}

at:

http://www.ve.org.za

Note:

This article is based on a paper delivered at the XIII European Conference on

Science and Theology, 7-11 April 2010, Edinburgh, Scotland.

(C) 2010. The Authors.

Licensee: OpenJournals

Publishing. This work

is licensed under the

Creative Commons

Attribution License.

\section{ABSTRACT}

The problem addressed in this article is twofold: firstly, how can a question be posed (on the naturalness of religion) consisting of two concepts (naturalness and religion) that are both somewhat vague and secondly, what are the implications of the preceding semantic mappings (or labelling) that determine the sense-making process (i.e. the conceptual problems that follows in the wake of the labelling). The aim of the article is to reflect from a historical perspective on the two concepts that make up the question, namely natural and religion and finally to indicate what is meant by semantic mappings that determine conceptual problems. From this indication it is argued that 'scientific foul play' is the order of the day, that is, that both theology and science are as it were playing 'off-side', thus making the question in the contemporary discourses an emotionally messy endeavour and that, in the author's opinion, the question has therefore to be rephrased.

\section{INTRODUCTION}

Science-inspired naturalism is a challenge for religion since it presents a view of the world that differs from traditional religious images.

(Drees 2003:596)

Make no mistake: the challenge and the different view of the world is a given. However, it is the confusing theological question posed as the 'naturalness of religion' that has to be rephrased.

(Daniël P. Veldsman)

In the field of organisational development, structure usually follows strategy. For the effective running and well-being of an organisation, the implication is that it first has to get its house in order with regard to how it sees itself (or positions itself within a specific environment), where it wants to go and what goals it wants to realise. Thus having formulated a strategic plan (let me call it the process of mapping), the organisation subsequently is structured.

Following this organisational dictum (as a positive directive), I want to translate it (as a negative problematising of the theme) theologically with regard to the question on the naturalness of religion and the challenge that it brings (as quoted by Drees), as follows: sense-making (or perhaps conceptualisation?) follows semantic mapping. My 'translation' from an organisational context to a theological context is perhaps not so good (at this stage), but I trust that at least it captures the basic thrust of the problem that I want to raise. ${ }^{1}$ I acknowledge that the density, width and depth of the issue at hand are surely not fully covered in this formulation. Certainly not. This can easily be substantiated in reference to - amongst others - the international project of the Ian Ramsey Centre (Oxford University) on the question of religion as natural human behaviour as well as recent influential publications on the naturalness of religion, such as Barrett's Exploring the natural foundations of religion (2000); Religion explained: The human instincts that fashion gods, spirits and ancestors (2001) by Pascal Boyer and his article 'Why is religion natural?' (2004) in the Skeptical Inquirer Magazine; Breaking the spell: Religion as a natural phenomenon (2006) by Daniel Dennett; Paul Bloom's article 'Religion is natural' (2007) in Developmental Sciences and the most recent, Supernatural as natural: A bio-cultural approach to religion (2010) by Michael Winkelman and John Baker. Following the much earlier publications of William Blake (1757-1827), there is also a strong contingent of supporters for the 'there is no natural religion' viewpoint. ${ }^{2}$

Although I will not be able to cover the full spectrum and all dimensions of the question on the naturalness of religion I would still like to pursue the question with my formulated directive. The problem that I would like to address is twofold: firstly, how can a question be posed (on the naturalness of religion) consisting of two concepts (religion and naturalness) that are not so clear ${ }^{3}$ and secondly, what are the implications of the preceding semantic mappings (or labelling) that determine the sensemaking process (that is, the conceptual problems that follow in the wake of the labelling)? In this paper my only aim is to try to clarify the twofold problem that is posed, that is: to reflect on the two concepts that make up the question, namely firstly natural and secondly religion and finally to indicate what is meant by semantic mappings that determine conceptual problems. From this indication I want to argue that 'scientific foul play' is the order of the day, that is, that both theology and science are as it were playing off-side, thus making the question in the contemporary discourses an emotionally messy endeavour and that, in my opinion, the question therefore has to be rephrased.

1.In his discussion of naturalism, Drees (2003:594) formulates the point that I am pursuing as follows: 'Explanations of facts always assume an explanatory framework of laws and earlier conditions'.

2.Perhaps the famous debate on natural theology between the two German scholars Karl Barth and Emil Brunner can be mentioned in this regard. It is especially Barth's negative stance which has influenced much of the reflection within Reformed circles on nature and natural.

3.Chris Wiltsher (2010) in his paper Can religion be natural? and Dirk Evers (2010) in his What's religion for? posed the very same question regarding the problematic and unclear understanding of the two concepts. 


\section{ON THE ‘NATURALNESS’ OF NATURAL}

More than a decade ago, the American philosopher-theologian Philip Clayton argued in God and contemporary science (1997) that the issue regarding the presumption of naturalism - that is, the assumption that the cause of any event in the natural world is a natural one as opposed to a supernatural one - is not whether there is any presumption of naturalism, but how strong we should make it and in which areas we should regard it to be strongest (cf. Clayton 1997:171-172). Furthermore, he states emphatically that the most serious presumption of naturalism is methodological (cf. Clayton 1997:173). However, I think that before one considers Clayton's conviction, there are serious qualifications to be considered beforehand; qualifications such as: how is the concept of naturalness to be understood? Or to put it differently: what is natural about naturalness?

The concept 'natural' is utilised in many contexts (philosophy, ethics, sociology, physics, etc.). What is immediately clear is that the varied contexts determine its varied meanings. ${ }^{4}$ Furthermore it is also utilised as an indication of a specific style in art, literature and theatre. Danto (1967) speaks of naturalism as a species of philosophical monism. He explains:

Naturalism ... is a species of philosophical monism according to which whatever exists or happens is natural in the sense of being susceptible to explanation through methods which, although paradigmatically exemplified in the natural sciences, are continuous from domain to domain of objects and events. Hence, naturalism is polemically defined as repudiating the view that there exists or could exist any entities or events which lie, in principle, beyond the scope of scientific explanation. In all other respects naturalism is ontologically neutral in that it does not prescribe what specific kinds of entities there must be in the universe or how many distinct kinds of events we must suppose to take place.

(Danto 1967:448)

The key conviction is thus that the entire knowable universe is composed of natural objects; ${ }^{5}$ key concepts are natural causes, natural processes, natural methods and natural explanations (Danto 1967:448-449; Post 1999:596-597), but also self-contained and self-dependent! In short: the natural world is the whole of reality. In a philosophical-theological context a naturalist is one who holds that there is nothing over and above nature. A naturalist, says Alston (1967a:145), is committed to rejecting traditional religion which is based on beliefs in the supernatural. ${ }^{6}$

Justifiably the Dutch philosopher Willem Drees (2003:593) mentions that naturalism arouses strong emotions. He states that some see it as a banner to follow whereas others see it as an enemy to fight. Drees continues by asserting that at the same time the concept represents a clear and unified category until one begins to think and read about it. This is precisely where the process to problematise the question will start.

\footnotetext{
4.See also, for example, the exposition of Mocek (1990:508) of the concept of nature in the Europäische Enzyklopädie zu Philosophie und Wissenschaften where he speaks of 'nature' as a 'Sammelbegriff zur Bezeichnung von Bereichen der Wirklichkeit, die ohne menschliches Zutun entstehen bzw. existieren. In diesem Sinnne wird Natur auch als Gegenbegriff zu den Begriffen "Kultur" bzw. "Gesellschaft" verwendet'. He then adds the important historical remark: 'Als philosophische Kategorie ist Natur über zwei-einhalb Jahrtausende mit verschiedensten Bedeutungen belegt, wobei die im frü die im frühn griechischen Denken auftauchenden zwei Grundbestimmungen einmal auf des Werden der Dinge gerichtet, zum anderen auf ihre Beschaffenheit, auf ihre Wesensart - vielfältige Interpretationen erfahren haben'.
}

5.In The dictionary of philosophy (cf. www.ditext.com/runes/n.html\#Naturalism) it is formulated as follows: 'Naturalism ... holds that the universe requires no supernatura cause and government, but is self-existent, self-explanatory, self-operating, and self-directing, that the world-process is not teleological and anthropocentric, but purposeless, deterministic and only incidentally productive of man ...'

6.Cf. Alston (1967a:145) for a clear explanation on the naturalist's position regarding religion that does not necessarily carry with it the rejection of religion as such. $\mathrm{He}$ states that many naturalists envisage a substitute for traditional religion which will states that many naturalists envisage a substitute for traditional religion which will
perform the typical functions of religions without making any claims beyond the natural world.
In the Dictionary of the history of ideas, Boas (1973) writes:

Nature, as norm, is the idea that 'nature' and 'natural' in one or more of their senses set the standard for the good life, both of the individual and of society. The words themselves have at least sixtysix senses distinguished by $A$ O Lovejoy and each of them has been the basis for praise and dispraise. But the multivalence of the word nature comes out very clearly when we think of some of those ideas to which it is antithetical: the supernatural, art, custom, the post-primitive as contrasted with the primitive. The natural is held by some to be better than the artificial, the customary, the contemporary. Of these four terms, only the supernatural is usually considered to be better than the natural.

(Boas 1973:346)

Many interesting and dated convictions mixed together make up Boas' perspective on nature, but what is important here are his remarks about 'setting the standards', the 'antithetical' as basis for the understanding of the term and the 'usual' consideration that the supernatural is better than the natural. That nature is the 'norm for setting the standards' (in whatever way it is understood) for the individual and for society are still semantically very operational. The unavoidable critical question is this: Who is setting which standards for whom and where? That the supernatural is to be considered better has surely not only been overturned, but has given rise in many contexts of reflection to the significance of evolutionary epistemology, to have been erased from 'sense-making' mapping altogether.' However, does this also imply that its methodological erasure (that is, of the concept 'supernatural') has done away with it its original 'antithetical' defining of the concept of nature from earlier generations? Or does the concept 'natural' today still carries with it a definite ideological residue of its earlier 'definition', but now minus the reference to supernatural that 'originally' determined its definition? How is this antithetical natural-supernatural relationship to be understood?

The semantic mapping of 'supernatural' (in opposition to that which is regarded as natural) is rather a 'latecomer' in the cultural history of the West (cf. Ward 2003:846) and its meaning and history depends entirely upon the order that it seems to supersede. ${ }^{8}$ The early church fathers hesitated to use the word, due to its older semantic resonance with the word 'natural', that is, the natural as the human condition without $\sin$, the pristine state in which was manifested the untarnished image of God (Ward 2003:846) - and such a natural condition was to be redeemed, not superseded. Although early cosmology did indeed conceive of realms, powers and principalities beyond the mundane, it was coined in a different semantic framework (e.g. ouranios / uperouranios / uperkosmios / supermandalis with its nature, i.e. its celestial essence, as uperousios, translated in Latin as supersubstantialis or superessentialis). Ward (2003:846847) explains insightfully that up to the 17th century, despite the current dualistic cosmology, the transit between the above and the below constituted a continuum. But then it changed with the terminological introduction of 'supernatural':

With supernaturalis a distinction was being made such that ... any incursions from the supernatural realm were understood as raptures of the natural order. As such, supernaturalis could only gain currency as that which was naturalis came to be understood as the order of things in the postlapsarian, rather than the prelapsarian, world.

(Ward 2003:847)

And the theological consequences? Against the historical background of the contribution of especially Thomas Aquinas,

\footnotetext{
7.Drees (2003:594) puts it as follows: 'Naturalism sees social and mental life as one of the fruits of the long evolutionary process'.

8.Ward (2003:846) refers to the French theologian Henri de Lubac, who has provided a significant history of the transmission of the word. De Lubac informs us that it was

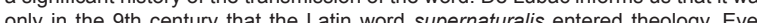
then its une then its usage was rare untilhe middle of the 13 h century and it did not come into standard use until after the Council of Trent in the middle of the 16th century (Ward 2003:846)
} 
the distinction between knowledge on the basis of revelation and knowledge on the basis of observation led increasingly to a division of intellectual labour and the examination of things created took on an independence that ultimately led to the establishment of 'Nature' (Ward 2003:847). ${ }^{9}$ 'Supernatural' became that which transcends the natural and is superior to the natural insofar as it is more powerful in being more spiritual (cf. Boas 1967:346; Ward 2003:847). However, this has changed dramatically. According to Abrams (cited in Ward 2003:847), the contemporary understanding of the supernatural is a cultural product of early romanticism and the processes of secularisation. ${ }^{10}$ Why secularisation? Because it brought about the demythologisation of human experience. But this process went hand in hand with the process of 'disenchantment' (Max Weber) brought about by the technological calculation and manipulation, that is, through the systematic rationalisation, of observable phenomena (Ward 2003:847). Thus we have a very different framework for understanding nature or natural, namely nature as the objectivist realm and natural as that which presents itself to the senses and can therefore be examined by the empirical sciences. It was a framework that gave rise to a spectrum of oppositions: subject and object; natural and cultural; private and public; the freedom of enlightenment and the dangerous darkness of ignorance (Ward 2003:848). The term 'supernatural' was now to be understood based upon these new binaries, that is, as the opposite of the natural (i.e. irrational; disordered; a realm of darkness; ignorance and superstition), as that which stood outside of the rational and integrated orders of nature.

However, post-modernity has brought about a new thrust in Western religiosity. A thrust - which I would like to vaguely call the re-emergence of religiosity - as cultural shift with respect not only to the credibility of the supernatural but also to its interface with the everyday (cf. Ward 2003:848). Reenchantment is emerging in many different ways over a wide cultural spectrum. ${ }^{11}$ But, in my opinion, this re-enchantment has first to be freed from its historical negative definition (i.e. supernatural as irrational opposite to nature) before we can pursue the question at hand, namely the naturalness of religion. But before I would like to formulate pointers in this regard, we first have to turn briefly to the concept 'religion'.

\section{HOW ‘RELIGIOUS’ IS RELIGION?}

The concept 'religion' immediately reminds of the well-known tactic of students of religion to cite the appendix of James $\mathrm{H}$ Leuba's Psychological study of religion (1912), which lists more than fifty definitions of religion, to demonstrate that the effort to define religion is a hopeless task (cf. Bowker 1997:xvff; Smith 1998:281). However, Smith (1998:281) convincingly responds, albeit short and sweet: 'Not at all!' This is not to say that religion cannot be defined. It can be defined with greater or lesser success more than fifty times. The crucial point that Smith (1998) emphasises is that religion is not a native term, but a term created by scholars for their intellectual purposes and is therefore theirs to define. ${ }^{12}$ He states:

[Religion] is a second-order, generic concept that plays the same role in establishing a disciplinary horizon that a concept such as 'language' plays in linguistics or 'culture' plays in anthropology. There can be no disciplined study of religion without such a horizon.

(Smith 1998:281-282)

9.Ward (2003:847) explains that by the time of the Council of Trent, 'nature' was becoming an autonomous, rule-governed realm open for systematic enquiry, manipulation and improvement.

10.See the exposition of Ward (2003:847) in which he indicates with modernity and the authority given to human reasoning, the increasing exploration and cataloguing of the natural world and with the continuing Protestant attacks upon superstition, the world became secularised.

11.Ward (2003:848) talks about the resurgence of the gothic imagination - about the cyborg, the clone, the alien, the android and cyberspace games.

12.See, however, the valid criticism of Auffarth and Mohr (2006:1613) of Smith's viewpoint regarding 'religion' as the sole creation of scholarly study.
Meeting the concept 'religion' for the first time, any scholar would be overwhelmed by the immense spectrum of definitions in literature on religion (cf. Ahn 1997:513ff; Alston 1967b:140ff; Auffarth \& Mohr 2006:1607ff; Bowker 1997:xvff; King 1987:282ff; McCutheon 2005:10ff; Rodrigues \& Harding 2009:1ff). There are narrow definitions and broad definitions; essentialist, functionalist, family resemblance definitions; typologies (higher and lower, prophetic, mystical, etc.); insider or outsider definitions; lists of so-called characteristic features or dimensions of religion (as worldview or belief system; as church; as ritual action; as ethics; as symbolic system; as feeling); explanatory expositions on definitions relating to historical processes and movements regarding the understanding of religion or religions and religious. ${ }^{13}$ Definitions addressing basic questions such as: Is there not after all something common to all religions that could be called 'religion'? Or: Is religion simply to be understood as a worldview, that is, as a system of belief which, though symbol and action, mobilises the feelings and wills of human beings (Ninian Smart)? King (1987) therefore adamantly states:

So many definitions of religion have been framed in the West over the years that even a partial listing would be impractical. With varying success they have all struggled to avoid, on the one hand, the Scylla of hard, sharp, particularistic definition and, on the other hand, the Charybdis of meaningless generalities.

(King 1987:283)

For Smith (1998), the anthropological definition of religion that has gained widespread assent among scholars of religion who both share and reject its functionalist frame is that religion is an institution consisting of culturally patterned interaction with culturally postulated superhuman beings (Spiro). He adds the following explanation:

This definition requires acceptance of a broad theory of cultural creation, signaled by the phrase 'culturally patterned' and 'culturally postulated' and places human cultural activities or institutions as the summum genus and religion as a subordinate taxon.

(Smith 1998:281)

According to Smith (1998), subsequent reformulations by scholars of religion have tended either to remove this subordination (e.g. Penner) or to substitute 'supernatural' for 'superhuman' (e.g. Stark \& Bainbridge). In this regard, Rodrigues and Harding (2009) state:

A defining feature of many religions, which separates them from other deeply absorbing and meaningful activities, is their concern with powers or agents that are regarded as mostly existing beyond the grasp of the five senses or instrumental apparatus. These spirits, gods or energies are thus 'supernatural' in that they transcend or are beyond the natural world.

(Rodrigues \& Harding 2009:3)

Auffarth \& Mohr (2006:1610-1611) come to the conclusion that there is no supra-cultural and supra-historical concept of religion. For them, scientific investigation can no longer select, a priori, by virtue of such a definition, what is religious or nonreligious in a culture. Following the Dutch scholar of religion Jacques Waardenburg, they talk of religion as an 'open concept'. ${ }^{14}$

13.See the insightful exposition of Smith (1998:269ff) in which he carefully explains the historical-semantic movements with regard to 'religion' (in relation to ritual practice), 'religions' (in relation to the existence of a multitude of articulations of religion) and 'religious' (in relation to the human experience or activity that it modifies). See also Auffrath and Mohr (2006:1608ff), who adds an important qualification in which the sute the the which they state that the word (religion) that so self-evidently escapes our lips in Europe and America today has a long history and a history principally European. Ahn 1997:514) also emphasises the 'eurozentrischen the historical-philosophical research of religion.

14.Interestingly Auffrath and Mohr (2006:1611-2) continue to give an exposition of a catalogue of criteria that distinguishes 'dimensions' or 'components' within a 'system of religion'. Following their occurrences, their connections and their social dynamics will enable one (according to them) to recognise a specific 'family' (system of kinship) of religion. In my opinion, McCutheon (2005:13) describes it neatly: "So what is religion? As with any other item in our lexicon, "religion" is a neally: "So what is religion? As why any other item in our lexicon, "religion" is a historical artifact that different social actors use for different purposes. to classify m. Whatever else it may or not may be, religion is at least an item of rhetoric that group members use to sort out their group identities.' 
Religion can thus be best understood as an umbrella concept. It packages the components and expressions of a combined field of facts and moulds an ideal type, a heuristic framework, a search screen with which the semantic mapping can be construed (cf. Auffarth \& Mohr 2006:1612). A new discourse, not only on religion (as Ahn 1997:514 states) but on the question of the naturalness of religion, has opened. And we have to keep in mind: the moral of the story is that the word 'religion' likely tells us more about the user of the word than it does about the thing being classified (McCutheon 2005:13).

\section{SEMANTIC MAPPING DETERMINING CONCEPTUALISATION: CONFUSION AND FOUL PLAY}

In the light of the preceding exposition, I would like to argue that the question on the naturalness of religion should be rephrased for three reasons. It should be rephrased firstly because of the complete lack of any scholarly consensus whatsoever regarding the two terms and secondly, because the historical semantic mapping (natural or religion) has left a confusing ideological residue on the contemporary conceptualisation of the question and thirdly, because it has given rise to, what I would like to call, scientific foul play, which finds expression in contemporary emotionally messy discourses on the relationship between science and theology.

Given the preceding exposition of the semantic mapping of 'natural' and 'religion' which unmasked a complete lack of scholarly consensus (cf. Evers 2010; Wiltsher 2010), I cannot avoid to conclude that the combination of natural plus religion in the phrase 'naturalness of religion' adds up to a non-sensible phrase. The question is highly questionable (non-sensible?) although it seems on the semantic surface to make complete sense. Clayton's acceptance of the presumption of naturalism is not so unproblematic after all (see page XX).

The confusing ideological residue with regard to 'nature' and 'natural' lies in its historically formed binary opposition to supernatural (observation vs revelation; rational vs irrational; order vs disorder, etc.), leaving us with a understanding of 'nature' as the objectivist realm, as the norm (paradigmatically exemplified in the natural sciences) for setting the (scientific) standards and 'natural' as that which presents itself to the senses and could therefore be examined by the empirical sciences. It repudiates the view that there exist any entities which lie in principal beyond the scope of scientific explanation. I call this the ideological residue which permeates the semantic mapping of nature and naturalness and which subsequently determines the conceptualisation that flows from them. The residue can be labelled from the perspective of the philosophy of science as 'positivism', that is, the epistemological perspective from which all (true and universal) knowledge is solely based on observation. However, after Thomas Kuhn's theory of paradigms and Karl Popper's evolutionary epistemological approach and the injection of Darwinism into philosophy of science, such a perspective is no longer tenable. It has opened a wide spectrum of new discourses on the evolution of human cognition, that is, that human rationality and therefore all reflection and knowledge are shaped and constrained by its deeper biological roots (cf. Van Huyssteen 2007:1). The theoryladenness and paradigm dependency of knowledge have since opened our eyes to the interpretative, hermeneutical dimension of all knowledge.

But it is not only the 'positivist' residue which clouds the problematic semantic mapping. Many theological traditions, in addressing the science-inspired naturalistic challenge (Drees 2003), has (methodologically and a-contextually) turned the older (antithetical) semantic resonance of natural as the human condition without sin into varied immunisation strategies, finding expression in (amongst others) contemporary fundamentalist approaches such as creationism and creationism light (intelligent design). Such pseudo-scientific-theological strategies are not only harmful to the integrity of theological discourses, but ignores the very exciting new space of interdisciplinary discourses that springs forth from the very illuminating insights of the interpretative, hermeneutical dimension of all knowledge.

If, as was stated earlier, the new thrust in Western religiosity (i.e. the re-emergence of religiosity) is to be appreciated theologically and a new discourse has to be pursued, I would suggest that it must be pursued enthusiastically within the epistemic space that opens up (between the natural sciences and theological reflection) from a rephrased question in this regard, such as: How does the biologically shaped human propensity for religious beliefs make sense? ${ }^{15}$

If the rephrased question is understood from the perspective of the evolution of human cognition (semantic map) and pursued (process of conceptualisation or sense-making) within the epistemic space that opens up between the natural sciences and theology, then it is of the utmost importance for both discourses to keep to the rules of their respective scientific selfunderstandings: the natural sciences will be guilty of 'playing off-side' in attempting to discredit reflection on the propensity for religious belief and thus on the existence or non-existence of God and to argue that religious belief is mere superstition. But theological reflection will also be 'playing off-side' if it tries to say more, to do more than that what faith perspectives allow it to confess or do. However, it is my experience that 'foul play' from both sides is the order of the day, making contemporary discourses a rather emotionally messy undertaking.

\section{REFERENCES}

Ahn, G., 1997, 'Religion', in C-J. Thornton (ed.), Theologische Realenzyklopädie, vol. 28, pp. 513-522, Walter de Gruyter, New York.

Alston, W.P., 1967a, 'Religion, naturalistic reconstructions of', in P. Edwards (ed.), Encyclopedia of philosophy, vol. 5, pp. 145147, Macmillan, New York.

Alston, W.P., 1967b, 'Religion', in P. Edwards (ed.), Encyclopedia of philosophy, vol. 5, pp. 140-147, Macmillan, New York.

Auffarth, C. \& Mohr, H., 2006, 'Religion', in K. von Stuckrad (ed.), The Brill dictionary of religion, pp. 1607-1619, Brill, Leiden.

Boas, G., 1973, 'Nature', in P.P. Wiener (ed.), Dictionary of the history of ideas, vol. 3, 346-351, Charles Schribner's Sons, New York.

Bowker, J., 1997, 'Religion', in J. Bowker (ed.), The Oxford dictionary of world religions, pp. xv-xxiv, Oxford University Press, Oxford.

Clayton, P., 1997, God and contemporary science, Edinburgh University Press, Edinburgh.

Danto, A.C., 1967, 'Naturalism', in P. Edwards (ed.), Encyclopedia of philosophy, vol. 5, pp. 448-451, Macmillan, New York.

Dictionary of philosophy, 2010, 'Naturalism', viewed 29 March 2010, from www.ditext.com/runes/n.html\#Naturalism

Drees, W.B., 2003, 'Naturalism', in J.W.V. van Huyssteen (ed.), Encyclopedia of science and religion, pp. 593-597, Thomson/ Gale, New York.

Evers, D., 2010, 'What's religion for?', paper presented at the XIII European Conference on Science and Theology, Edinburgh, Scotland, 7-11 April 2010.

Henriksen, J-O., 2003, 'Human nature, religious and philosophical aspects', in J.W.V. van Huyssteen (ed.), Encyclopedia of Science and Religion, pp. 435-440, Thomson/ Gale, New York.

15.With this formulation I am not implying that the 'biological' approach represents the only meaningful approach to the topic at hand. It does not. Nor do I see the biological approach as covering all the complexities involved in the human propensity for religious belief. I only want to emphasise an angle from which I consider the question to be approached in an insightful manner. See in this regard Lluis Oviedo (2008) 
King, W.L., 1987, 'Religion', in M. Eliade (ed.), The encyclopedia of religion, pp. 282-293, Macmillan, New York.

Mocek, R., 1990, 'Natur', in H.J. Sandkühler (ed.), Europäische Enzyklopädie zu Philosophie und Wissenschaften, pp. 508-515, Felix Meiner Verlag, Hamburg.

McCutheon, R.T., 2005, 'Understanding religion', in C. Partridge (ed.), The world's religions, pp. 10-13, Lion Book, Oxford.

Oviedo, L., 2008, 'Is a complete biocognitive account of religion feasible?', Zygon 43(1), 103-126.

Post, J.F., 1999, 'Naturalism', in R. Audi (ed.), The Cambridge dictionary of philosophy, pp. 596-597, University Press, Cambridge.

Rodrigues, H. \& Harding, J.S., 2009, Introduction to the study of religion, Routledge, New York.
Smith, J.Z., 1998, 'Religion, religions, religious', in M.C. Taylor (ed.), Critical terms for religious studies, pp. XX, University of Chicago Press, Chicago.

Van Huyssteen, W., 2007, 'A brief overview of a theologian's journey to interdisciplinarity', unpublished paper, James I McCord professor of Theology and Science, Princeton Theological Seminary.

Ward, G., 2003, 'Supernaturalism', in J.W.V. van Huyssteen (ed.), Encyclopedia of science and religion, pp. 846-848, Thomson/ Gale, New York.

Wiltsher, C., 2010, 'Can religion be natural?', paper presented at the XIII European Conference on Science and Theology, Edinburgh, Scotland, 7-11 April 2010. 